
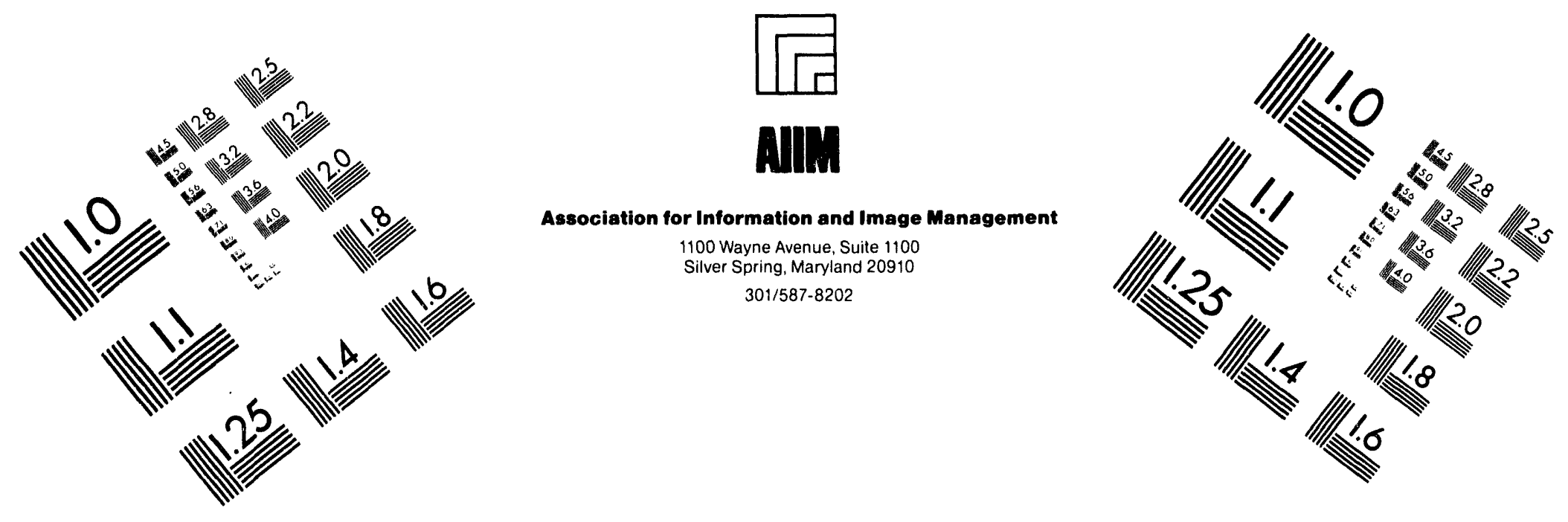

Centimeter

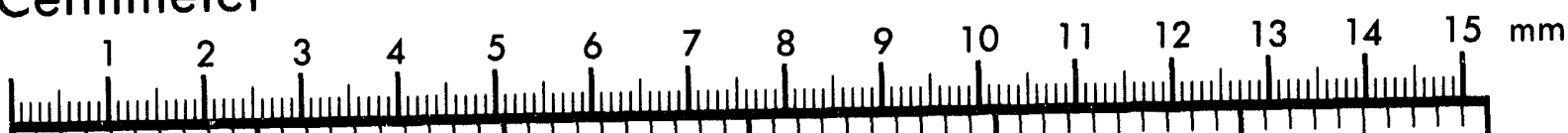

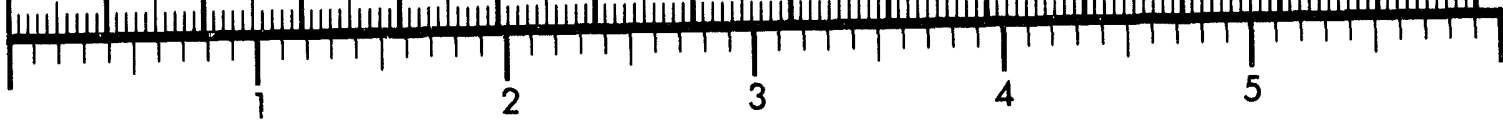
Inches
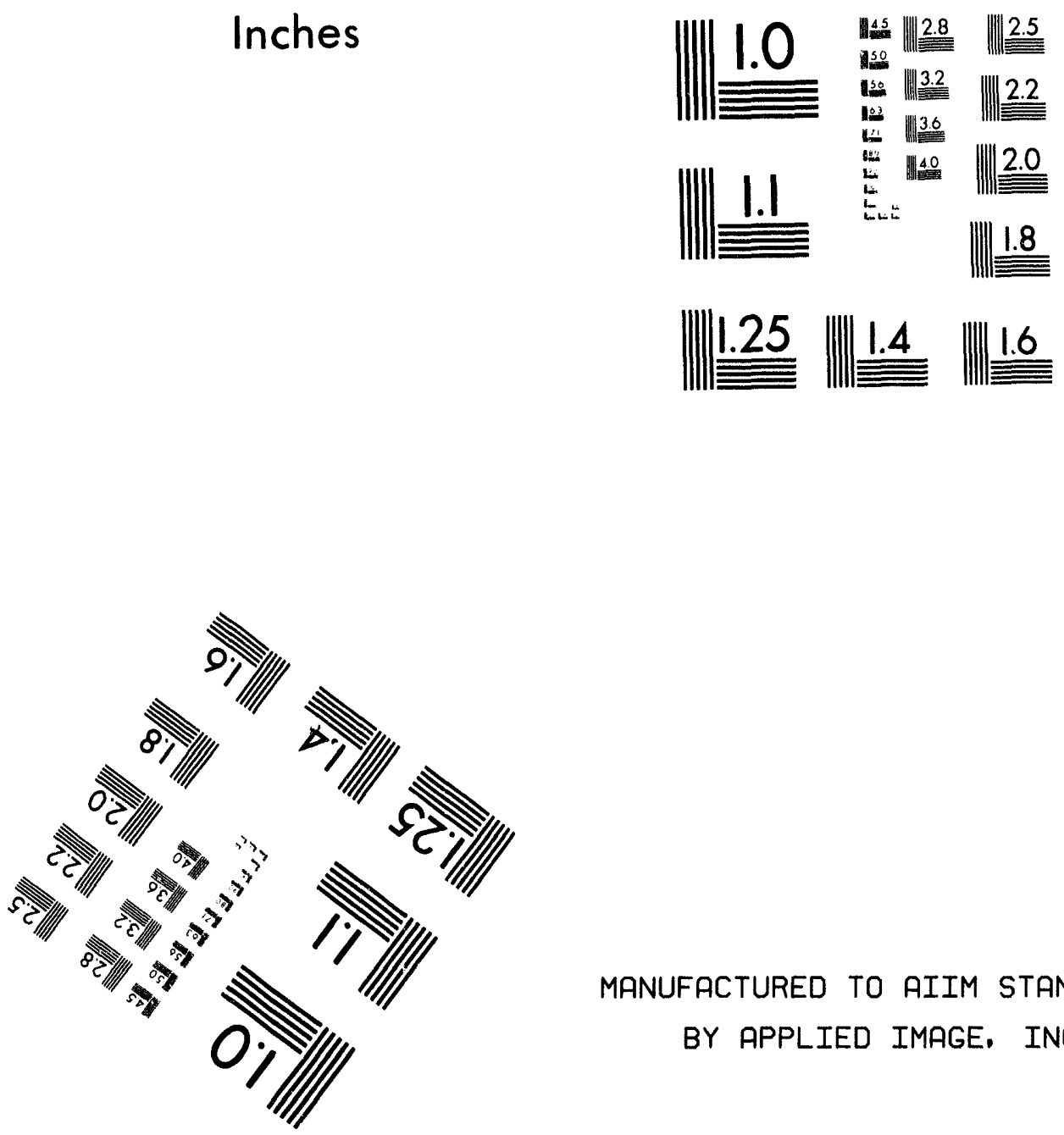

MANUFACTURED TO AIIM STANDARDS BY APPLIED IMAGE, INC.

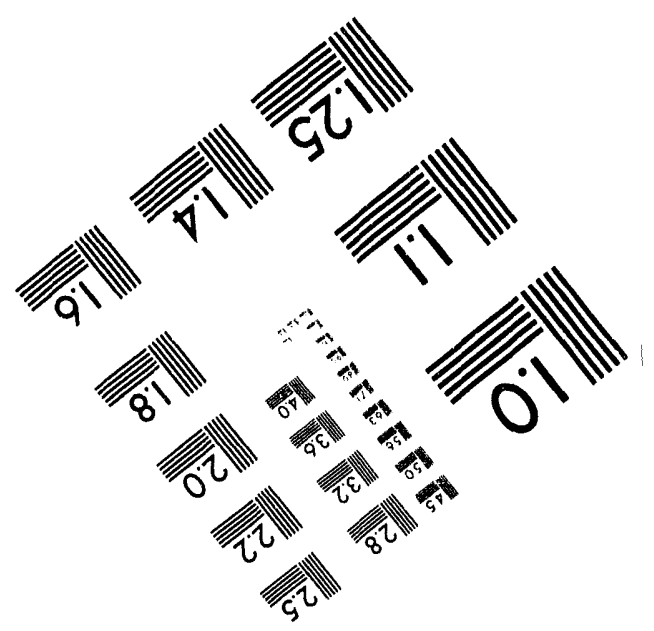



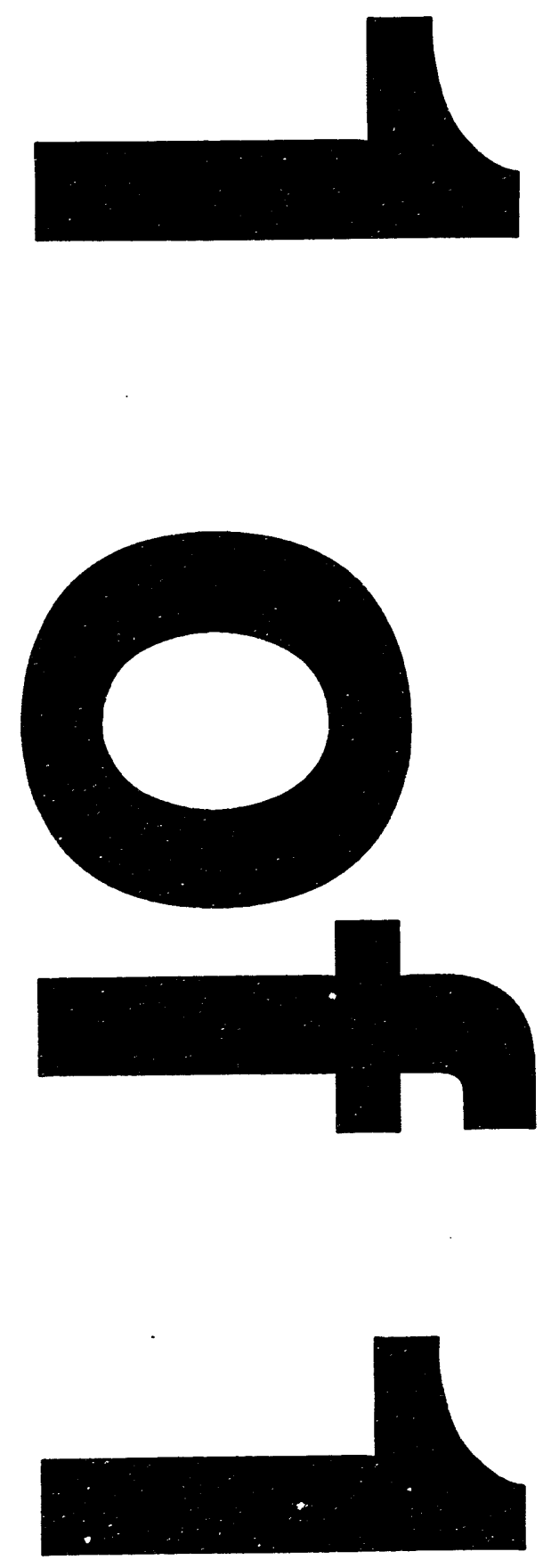
DOE/RL-92-28

Revision 1

UC-630

\section{Columbia River Impact Evaluation Plan}

Date Published

March 1994

\section{DISCLAIMER}

This report was prepared as an account of work sponsored by an agency of the United States Government. Neither the United States Government nor any agency thereof, nor any of their employees, makes any warranty, express or implied, or assumes any legal liability or responsibility for the accuracy, completeness, or usefulness of any information, apparatus, product, or process disclosed, or represents that its use would not infringe privately owned rights. Reference herein to any specific commercial product, process, or service by trade name, trademark, manufacturer, or otherwise does not necessarily constitute or imply its endorsement, recommendation, or favoring by the United States Government or any agency thereof. The views and opinions of authors expressed herein do not necessarily state or reflect those of the United States Government or any agency thereof.

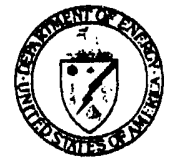

United States Department of Energy P.O. Box 550

Richland, Washington 99352

DISTRIBUTION OF THIS DOCUMENT IS UNLIMITED 
DOE/RL-92-28, Rev. 1

\section{ACRONYMS}

CERCLA Comprehensive Environmental Response, Compensation, and Liability Act

DOE

U.S. Department of Energy

DOW

DQO

Descriptions of Work

data quality objectives

Ecology

EPA

HEIS

Washington State Department of Ecology

HWMA

NPL

RCRA

RFI/CMS

U.S. Environmental Protection Agency

Hanford Environmental Information System

U.S. Hazardous Waste Management Act

National Priorities List

Resource Conservation and Recovery Act

$\mathrm{RI} / \mathrm{FS}$

RCRA facility investigations/corrective measures studies remedial investigations/feasibility studies 
DOE/RL-92-28, Rev. 1

\section{CONTENTS}

1.0 INTROOUCTION . . . . . . . . . . . . . . . . . . 1

2.0 PROPOSED DATA COLLECTION PLAN . . . . . . . . . . . . . . . . 2

2.1 COLUMBIA RIVER IMPACT EVALUATION SUMMARY . . . . . . . . . . . 2

2.2 PROPOSED DATA COLLECTION ACTIVITIES ............... . . . . 3

2.2.1 Data Quality Objectives .............. . . 4

2.2.2 Recommended Hanford Reach Investigation Tasks . . . . . 6

2.2.3 Proposed Schedule . . . . . . . . . . . . 15

3.0 REFERENCES ........................... 18

TABLES:

1-1 Proposed Activity Schedule ... . . . . . . . . . . . . 17 


\subsection{INTRODUCTION}

As a result of past practices, four areas of the Hanford Site (the 100, 200,300 , and 1100 Areas) have been included on the U.S. Environmental Protection Agency's (EPA) National Priorities List (NPL) under the Comprehensive Environmental Response, Compensation, and Liability Act of 1980 (CERCLA). In addition to the four NPL sites, there are over 60 Resource Conservation and Recovery Act of 1976 (RCRA) treatment, storage, or disposal facilities that will be closed or permitted to operate in accordance with RCRA regulations. To accomplish the timely cleanup of the past-practice units, the Hanford Federal Facility Agreement and Consent Order (Tri-Party Agreement), (Ecology et al. 1989) was signed by the Washington State Department of Ecology (Ecology), EPA, and the U.S. Department of Energy (DOE).

Milestones were adopted to support the Tri-Party Agreement. These milestones represent the actions needed to ensure acceptable progress toward Hanford Site compliance with CERCLA, RCRA, and the Washington State Hazardous Waste Management Act of 1976 (HWMA). This plan was prepared to fulfill the requirement of Tri-Party Agreement Milestone M-30-02 (DOE-RL 1991), which requires a plan to determine cumulative health and environmental impacts to the Columbia River in the 100 Areas. This plan supplements the CERCLA remedial investigations/feasibility studies (RI/FS) and RCRA facility investigations/corrective measures studies (RFI/CMS) that will be undertaken in the 100 Area.

To support the plan development process, existing information was reviewed and a preliminary impact evaluation based on this information was performed. The purpose of the preliminary impact evaluation was to assess the adequacy of existing data and proposed data collection activities in order to support a future baseline risk assessment that will determine the cumulative human health and environmental impacts to the Columbia River. Based on the results of the evaluation, this plan is proposed to collect additional data or to make changes to existing or proposed data collection activities. This plan is limited in scope to the part of the Columbia River along the 100 Area of the Hanford Site.

In May 1991, the Tri-Party Agreement was amended by the Hanford Federal Facility Agreement and Consent Order Change Package (DOE-RL 1991) and Milestones M-30-00 through M-30-05 were proposed to guide data collection activities in the 100 Area. These Milestones were added to implement the Hanford Site Past-Practice Strategy and complement the rescoping of 100 Area operable unit work plans. The goal of these 100 Area milestones is to develop a focused and comprehensive review of available data on current river impacts in the 100 Area and to coordinate remedial investigation activities in the operable units that are related to the Columbia River.

The purpose of this report is to satisfy Milestone M-30-02, which is to "Submit a plan (primary document) to EPA and Ecology to determine cumulative health and environmental impacts to the Columbia River, incorporating 
results obtained under M-30-01." Milestone M-30-01 is, "Submit a report (secondary document) to EPA and Ecology evaluating the impact to the Columbia River from contaminated springs and seeps as described in the operable unit work plans 1 isted in M-30-03."

To satisfy Milestone M-30-02, a preliminary impact evaluation was conducted to assess the adequacy of existing data and proposed data collection programs for evaluating cumulative health and environmental impacts to the Columbia River due to past practices at the Hanford Site. The results of this evaluation were used to develop this plan to ensure collection of sufficient data for adequate characterization of the Columbia River along the 100 Area for CERCLA purposes. The evaluation used to develop the plan is not a risk assessment; the plan presented here is only a mechanism to collect additional data to support a future risk assessment. The Columbia River risk assessment will be completed under Federal Facility Agreement and Consent Order milestone M-30-80B (January 25, 1994).

\subsection{PROPOSED DATA COLLECTION PLAN}

A summary of the impact evaluation is provided in Section 2.1. Based on the findings and data gaps identified, recommendations for further Hanford Reach characterization and monitoring activities were developed and are presented in Section 2.2. Specific plans (e.g., Descriptions of Work [DOW]) will be developed for implementation of the necessary activities.

\subsection{COLUMBIA RIVER IMPACT EVALUATION SUMMARY}

The Hanford Reach is the last free-flowing, nontidal stretch of the Columbia River in the United States. As such, it has many important ecological functions, including providing important spawning grounds for salmon and steelhead trout and sensitive (or possibly critical) habitat for endangered and threatened species, including bald eagles, white pelicans, and persistentsepal yellowcress.

The shoreline along the Hanford Reach is largely undeveloped due to the presence of the Hanford Site. The Hanford Site is a DOE facility that was used from 1943 to 1981 for research and production of nuclear materials used in defense and energy. From 1943 to 1971, the Columbia River was used as a source of cooling water in as many as nine nuclear reactors that were used to produce plutonium. As a result of plutonium-production activities in the 100 Area, there have been significant quantities of contaminants (radionuclides and nonradionuclides) released to the Hanford Reach.

Radionuclides attributable to Hanford operations were detected in virtually all components of the ecosystem during reactor operations, but the Hanford Reach retains many of its functional qualities:

- Salmon spawning has been increasing in the recent past.

- Threatened and endangered species continue to use the Reach for habitat. 
- For most contaminants, there is little significant difference in river-water quality between sampling points that are upstream and downstream of the Hanford Site.

Although there is evidence that shows contaminants may have localized impacts within the Hanford Reach, results of environmental monitoring conducted to date do not show any significant adverse biological responses to the Hanford Reach ecosystem. This is a preliminary assessment based on impacts as defined by past studies conducted at the Hanford Site. Other interpretations of ecological impacts (e.g., measurements of specific endpoint effects) will need to be considered in future Baseline Risk Assessments.

\subsection{PROPOSED DATA COLLECTION ACTIVITIES}

During the preparation of this preliminary assessment, data gaps have been identified pertaining to the ability during the RI and RFI processes to evaluate impacts to the Hanford Reach attributable to past or present operations of the 100 Area. These data gaps and corresponding data needs can be classified by contaminant migration pathway:

- Contaminant input pathways (i.e., discharge of 100 Area affected groundwater and other sources of contaminant input to the Reach)

- Surface water pathways

- River sediment pathways

- Biological pathways.

Additional specific data are needed for each of these pathways to improve the conceptual understanding of contaminant movement and effects within the Columbia River habitat and to conduct meaningful RI and RFI baseline risk assessments.

Much of the information needed to evaluate the migration and effects of contaminants released from 100 Area facilities is presently collected under ongoing Sitewide environmental monitoring programs or will be generated by the operable unit-specific facility and remedial investigations planned for the 100 Area. This section provides a plan to maximize the utilization of these ongoing and planned efforts to collect a sufficient amount of the data to allow for a conclusive assessment of baseline risks associated with contaminants within the 100 Area.

The scope of the preliminary impact evaluation presented in this report, along with the scope of the conceptual data collection program plan presented below in Subsection 2.2.2, is confined to 100 Area effects on the Columbia River. However, the consideration of spatial, ecological, temporal, and administrative factors for any investigation points to an eventual need for characterizing the river on a programmatic basis. 
The most effective and efficient long-term investigation unit for the river appears to be the Hanford Reach, which can be defined as that segment of the river bounded by Priest Rapids Dam down to the head of Lake Wallula; however, the lower boundary should be extended downstream of Hanford for the purpose of investigation of sediment and biotic media. Therefore, it is recommended that consideration be given to treating the river as a whole for the purpose of consolidating resources and increasing efficiency of actions required to comply with Tri-Party Agreement requirements.

Subsection 2.2.1 discusses the data quality objectives for this river characterization program. A conceptual approach for generating the required data to allow for proper characterization of the river is presented in Subsection 2.2.2 in the form of an outline of recommended river investigation tasks.

\subsubsection{Data Quality Objectives}

The central rationale for undertaking a preliminary impact assessment of the Columbia River was to propose an efficient data collection program that will result in a characterization of the threats posed to the river and its associated receptors within the 100 Area of operations. Prior to proposing such a data collection program, specific data quality objectives (DQO) must be considered. There are the three stages in the DQO development process (EPA 1987):

- $\quad$ Stage 1 - Identification of decision types

- Stage 2 - Identification of data uses and needs

- Stage 3-Data collection program design.

Each of these stages is discussed in Paragraphs 2.2.1.1, 2.2.1.2, and 2.2.1.3, respectively, to provide an understanding of the logic behind the development of the proposed river investigation plan for the 100 Area of the Hanford Site.

2.2.1.1 Stage 1-Identification of Decision Types. This stage of the DQO development process entails the evaluation of available data, the development of a site-specific conceptual model, and the specification of objectives for the data collection program (EPA 1987).

The results of the available data evaluation allow specific data collection program objectives to be developed. Before listing such objectives for each of the four contaminant migration pathway elements (contaminant inputs, surface water, river sediments, and biota), appropriate boundaries for the data collection program must be considered (Beanlands and Duinker 1983; National Research Council Commission on Life Sciences, Committee on the Applications of Ecological Theory to Environmental Problems 1986).

The following objectives for each of the four contaminant migration pathway elements are confined to the 100 Area.

Objectives specific to the contaminant input pathway element can be divided into two parts: inputs to the reach from the discharge of 
groundwater affected by 100 Area operations and inputs to the reach from other sources of contamination. Objectives pertaining to the first are as follows:

- Identification of contaminants of potential concern in the groundwater affected by 100 Area operations

- Definition of the magnitude and locations of contaminant fluxes to the Hanford Reach

- Definition of the mechanisms and effects of contaminant transport specific to the process of groundwater discharging to the river water column through sediments and their associated interstitial waters

- Determination of the speciation of chromium (which the preliminary impaci assessment shows to be one of the most potentially significant river contaminants associated with the 100 Area) in the river sediments and water column.

The following are objectives specific to the characterization of contaminant inputs to the reach from sources other than the 100 Area:

- Identification of other sources currently affecting the 100 Area of the Hanford Reach (e.g., groundwater and surface water discharges affected by regional agricultural operations)

- Definition of the nature, magnitude, and locations of contaminant fluxes from these other sources.

Speciation of certain contaminants of potential concern attributable to non-100 Area sources may also be necessary to distinguish Hanford versus non-Hanford impacts. element:

The following are objectives specific to the surface water pathway

- Definition of impacts to the water column for all contaminants of potential concern identified for the 100 Area

- Evaluation, selection, and implementation of an appropriate code(s) for characterizing dispersion of contaminants in the water column of the Hanford Reach.

The river sediment pathway objectives are as follows:

- Definition of impacts to the sediments for all contaminants of potential concern identified for the 100 Area

- Evaluation, selection, and implementation of an appropriate code(s) for characterizing transport and deposition of contaminants in the sediments of the Hanford Reach. 
Finally, the objectives specific to the biological pathway element are as follows:

- Compilation of ecotoxicological data needed to assess risks associated with all contaminants of potential concern identified for the 100 Area

- Evaluation of ongoing biocontaminant monitoring being conducted on the Hanford Reach

- Compilation of information on sensitive and critical habitats in and along the Hanford Reach.

2.2.1.2 Stage 2 - Identification of Data Uses and Needs. The second stage of the DQO development process consists of the identification of data quality needs and the selection of a sampling approach to fulfill such needs. Wich regard to data quality, all samples obtained under the proposed data collection program should be subjected to analytical protocols set forth in published standard methods. This approach will ensure that all data generated will be of state-of-the-practice quality. Coordinates of locations sampled under this plan will be identified in State Plane Coordinates (NAD 83); sampling data will be entered into the Hanford Environmental Information System (HEIS). With regard to recommended sampling approaches, a conceptual level of detail is provided within the recommended river investigation tasks presented in Subsection 2.2.2.

\subsubsection{Stage 3-Data Collection Program Design. The third and final} stage of the DQO development process consists of the design of a data collection program to satisfy the established objectives. Subsection 2.2.2 describes the general approach to the data collection program and presents conceptual level detail for the various recommended tasks and associated activities.

The tasks and activities recommended will optimize the utilization of existing monitoring programs for the Hanford Reach and the planned operable unit-specific remedial and facility investigation program for the 100 Area. Specific details for this program are therefore deferred to any necessary additions to the existing environmental monitoring programs or to 100 Area Operable Unit work plans, as appropriate. If additional work not covered under one of these established or planned programs is required, DOWs will be developed to provide specific details for such components of the overall data collection program for the Hanford Reach.

\subsubsection{Recommended Hanford Reach Investigation Tasks}

As stated in Section 1.1, the impetus for this report is Tri-Party Agreement Milestone M0-30-02, which requires that a plan be developed to determine cumulative impacts to the Columbia River. The M-30 milestones were developed to provide guidance for integration of general investigations and studies for the 100 Area. Consequently, this report, including the recommended reach characterization plan below, focuses on the 100 Area segment of the Hanford Reach, which encompasses that portion of the reach extending from Vernita Bridge downstream to the Hanford Townsite. 
The proposed reach investigation tasks are organized by the objectives, estabi ished in Paragraph 2.2.1.1, within each of the four contaminant migration pathway elements. Activities associated with characterization of contaminant inputs are outlined in Paragraph 2.2.2.1; those associated with surface water are outlined in Paragraph 2.2.2.2; those associated with river sediments are outlined in Paragraph 2.2.2.3; and those associated with biota are out1ined in Paragraph 2.2.2.4.

\subsubsection{Task 1 - Characterization of Contaminant Input Pathways. As} indicated in Paragraph 2.2.1.1, contaminants are currently entering or have the potential to enter the Hanford Reach either by means of discharge of groundwater affected by 100 Area operations, or by other pathways. Two subtasks are proposed: Subtask $1 A$ to address the characterization of 100-Area-affected groundwater inputs to the Reach, and Subtask 1B to address the characterization of the other input pathways. These subtasks are described below in Subparagraphs 2.2.2.1.1 and 2.2.2.1.2, respectively.

\subsection{Subtask $1 \mathrm{~A}$ - Characterization of 100 Area Contaminated}

Groundwater Inputs. Paragraph 2.2.1.1 establishes four objectives for this subtask: identification of contaminants of potential concern, definition of contaminant fluxes to the reach, definition of contaminarit mixing in the groundwater discharge zones, and speciation of chromium within the sediments and water column of the reach. Each of these objectives is addressed by a respective subtask activity and discussed below.

\section{Activity $1 \mathrm{~A}-1$ - Identification of Contaminants of Potential Concern.}

Contaminants of potential concern will be identified in accordance with the procedure established in DOE-RL (1992a) and the 100 Area operable unit work plans. As the action should take place on an operable-unit-byoperable-unit basis, Activity $1 A-1$ will consist of compilation and integration of the contaminant identification results for the 100 Area investigations and will be addressed in the Limited Field Investigations (LFI) report for each operable unit.

Activity 1 A-2 - Characterization of Contaminant Fluxes.

Groundwater discharges to the Hanford Reach through surficial springs adjacent to the river and through subsurficial seepage through the river sediments. Flow rates for springs are difficult if not impossible to obtain; therefore, the only way to quantify the flux of a given contaminant along this pathway is through characterization of groundwater flow and contaminant transport. Knowledge of contaminant flux is essential to allow for prediction of potential reach-related impacts to human health and the environment.

The groundwater investigations planned for the operable units mentioned above under Activity $1 \mathrm{~A}-1$ should generate data necessary to determine the locations and magnitudes of the fluxes of the various contaminants of potential concern to the Hanford Reach. The preliminary contaminant transport evaluation utilized very conservative fluxes and assumed that they entered the reach in a point-source manner. Groundwater operable unit investigations are expected to provide more realistic information concerning both flux magnitude and location (as opposed to a one-dimensional point 
DOE/RL-92-28, Rev. 1

source inputs, RI and RFI information should allow for two-dimensional area source inputs).

As flux information should be developed on an operable-unit-byoperable-unit basis, Activity 1A-2 will consist of compilation and integration of the groundwater contaminant transport results obtained for the 100 Area groundwater operable units. This activity will also consist of the compilation of data generated from the spring monitoring program. This information will be provided with the FS report for each operable unit.

\section{Activity $1 \mathrm{~A}-3$ - Characterization of Contaminant Mixing in Discharge Zones.}

A potentially applicable remediation standard for the 100 Area is the State of Washington's surface water cleanup standards promulgated in the "Model Toxics Control Act Cleanup Regulation" ([MTCACR] WAC 173-340-730). Under WAC 173-340-730(6)(b), no dilution zone is allowed to demonstrate compliance with the calculated standard when a surface water body is impacted by contaminant discharges through groundwater.

However, the actual cleanup standards to be used have not been decided by the Tri-Parties. The purpose of this activity is therefore to obtain empirical information to allow for a better understanding of contaminant mixing in the affected groundwater discharge zones in the 100 Area. Given the size of the Columbia River, the effects of mixing (as demonstrated by the results of the preliminary impact evaluation completed for this report) are expected to be substantial. This activity is thus needed to provide conclusive evidence that cleanup standards based on water quality standards will adequately protect both human health and the environment, and that water quality standards applied to interstitial water will be protective of the environment.

The 100 Area groundwater investigations mentioned above under Activities $1 A-1$ and $1 A-2$ will provide information on the magnitude of contamination in the groundwater medium. Recently conducted near-shore surface water characterization results show that the concentrations of anticipated contaminants of concern are generally below standard analytical detection limits (DOE-RL 1992b); however, no data are available to provide a characterization of the quality of the interstitial waters of the river sediments.

This activity will therefore consist of a focused characterization of the groundwater, sediment, interstitial water, and water column components of one of the major contaminated groundwater discharge zones in the 100 Area. It is recommended that the $100 \mathrm{D}-1$ plume be selected, as the results of the preliminary impact assessment indicated that the levels of chromium contamination within this plume have the potential to contribute significantly to any impact to the Hanford Reach environment. Using the 100D-1 plume to evaluate mixing will be efficient, because this same plume can be used for the chromium speciation investigation discussed below under Activity $1 \mathrm{~A}-4$, thus allowing for logistical consolidation of these two activities. If the 1000-1 plume is not practical, induced tracer studies with another plume will be considered. 
Proposed data collection under this task will interface with the activities resulting from Milestone M-30-05, which is "Install all field instrumentation and initiate monitoring activities necessary to perform long-term evaluation of Columbia River and unconfined aquifer interaction, in accordance with tasks defined in operable unit work plans listed in M-30-03." Monitoring conducted for Milestone M-30-05 will provide the data to characterize the groundwater mixing zone. A separate report to meet this activity will be produced by March 1995 to incorporate one year of monitoring, to begin in October 1993.

Activity $1 \mathrm{~A}-4$ - Chromium Speciation.

The results of the preliminary impact assessment presented in this report indicate that chromium is a 100 Area contaminant expected to be one of the most significant with respect to impact potential in the Hanford Reach. This conciusion, however, assumes that all hexavalent chromium in the groundwater remains in this valence state in the river water column. Hexavalent chromium is thermodynamically unstable in soils and natural surface waters, provided a sufficient amount of a reducing agent such as organic material is present (Dragun 1988, Syracuse Research Corp. 1991). However, reaction kinetics are slow. If reduction occurs, the hazard associated with chromium is greatly decreased because the trivalent oxidation state is much less toxic than the hexavalent state and also much less soluble. Thus, an investigation of the speciation of chromium in the various environmental media of the 100 Area and Hanford Reach could possibly clarify the impact potential attributable to chromium.

It is recommended, based on the findings of the preliminary impact assessment, that this activity be focused on the 100D-1 plume, as this plume appears to have the greatest chromium flux. An activity-specific DOW will be developed to provide detailed guidance on sample collection and analysis and on data evaluation. Efforts should encompass the groundwater, the river sediments, the interstitial waters of the river sediments, and the river water column. The importance of the 100 Area segment of the Hanford Reach as a salmonid spawning ground makes knowledge of chromium valence state in the sediments and interstitial waters essential, as hexavalent chromium has a corrosive effect on biological tissue.

In addition to sampling for total and hexavalent chromium, other relevant environmental parameters - such as $\mathrm{pH}$, Eh, total organic carbon (TOC), and dissolved oxygen (DO) - should be included. Sampling and analysis efforts should be accompanied by a literature review to document current understanding of the environmental behavior of chromium. If for some reason it is not practical to conduct the investigation on the 100D-1 plume, the 100H-1 or 100K-2 plumes should be considered as backup locations for the field effort, as the latter two plumes are estimated to have the second highest fluxes of chromium to the Reach.

There are five groundwater operable unit work plans currently under development for the 100 Area. The operable unit workplans show that groundwater characterization will not include any chromium speciation. Therefore, a DOW will need to be developed that will identify sampling techniques and analytical methods necessary to fulfill this data collection activity. 
DOE/RL-92-28, Rev. 1

2.2.2.1.2 Subtask 1B - Characterization of Other Contaminant Inputs. If significant adverse impacts to human health or the environment are identified during the 100 Area impact assessment, additional work may be required to determine if contaminants are of Hanford or non-Hanford origin. Subtask 1B activities cover that contingency. Section 2.2.1.1 establishes at least two objectives for this subtask: (1) identification of other sources if needed and (2) characterization of contaminant fluxes. It may al so be necessary to speciate certain contaminants identified; however, such a determination is contingent on the findings of the activity implemented to fulfill the contaminant identification objective. The subtask activities proposed to meet the two objectives are discussed below.

Activity 1B-1 - Identification of Other Contaminant Input Sources.

As indicated in Paragraph 2.2.1.1, sources of contaminant input to the Hanford Reach along the 100 Area other than groundwater affected by 100 Area operations exist. Examples of such other sources include groundwater and surface-water discharges affected by regional agricultural operations.

A long-term information compilation effort will be performed under this activity to identify other sources of potential contaminant input that affect Hanford Reach along the 100 Area, such as other agricultural discharges, irrigation return water, permitted and nonpermitted point: sources, and contributions of designated hazardous substances from natural sources or from widespread anthropogenic activity (e.g., motor vehicle operation, past atmospheric nuclear testing, pesticide application, and fertilizer application).

If data collected during the information compilation effort are insufficient to conduct future 100 Area risk assessments, it is conceivable that this information compilation activity will identify a need to conduct a specific sampling, analysis, and data evaluation activity to support the identification of other contaminant sources. If such a need arises, a new activity will be defined and an activity-specific DOW will be developed to provide detailed guidance on such sample collection, analysis, and data evaluation. Any such DOW should address not only identification of sources, but identification of contaminants of potential concern in such sources and quantification of contaminant fluxes from such sources (see Activity 1B-2 below), as well.

If implementation of Activity 18-1 finds that insufficient data are available to identify contaminants of potential concern in non-Hanfordrelated sources having the potential to affect the Hanford Reach, a new sampling, analysis, and evaluation activity, supported by a DOW, will have to be developed for Subtask 1B, as mentioned under Activity 1B-1.

Activity $1 \mathrm{~B}-2$ - Characterization of Contaminant Fluxes.

As demonstrated in the discussion under Activity 1A-2, contaminant flux data are essential to allow for prediction or estimation of impacts to the Hanford Reach. The only way to quantify such fluxes through the groundwater medium is through characterization of groundwater flow and contaminant transport. Surface water sources, particularly in the form of irrigation return water, are expected to be a potentially significant contributor of 
hazardous substances to the Hanford Reach. As is the case with groundwater, both water quality and flow data are needed to quantify flux from this medium.

\subsubsection{Task 2 - Characterization of Surface Water Pathways. Contaminants} entering the Hanford Reach from discharging groundwater that has been affected by 100 Area operations have a high potential to enter and be transported by the flowing water column of the river. The surface water medium of the Hanford Reach is a highly valuable resource in the region for both human and nonhuman organisms. Therefore, a definitive characterization of this pathway is important.

Two activities are proposed under this task and are discussed below, one to define impacts to the water column through monitoring, the second to evaluate, select, and implement an appropriate surface water dispersion code or codes to allow for prediction of the magnitude and extent of contamination within the water column of the reach.

\section{Activity 2-1 - Surface Water Monitoring.}

The ongoing Pacific Northwest Laboratory (PNL) environmental monitoring program for the Hanford Site includes water quality monitoring for the Hanford Reach. This current program collects control samples from either Vernita Bridge or Priest Rapids Dam and evaluates potential impacts from downstream samples collected at the City of Richland water intake. The current program also focuses primarily on radiological substances.

With relatively minor additions, the current PNL program forms an excellent platform from which to collect data to assist in developing a cumulative impact assessment for the Hanford Reach, in addition to the program's long-term environmental monitoring function. In order to adapt the program for this purpose, this activity will include an evaluation of sampling locations, sampling frequencies, and analytes.

Current sampling frequencies are anticipated to be adequate for the purposes of cumulative impact evaluation. However, additional sampling locations should be considered. For example, a water intake that supplies potable water to the 100 and 200 Areas is located in the 100-B Area. A backup intake for this system is located in the 100-D Area. Another location would be downstream of the 100 Areas to help distinguish any 100 Area contamination contributions from other areas. Data from samples at these locations should be consistent with and evaluated with the surface water monitoring program.

As the current program focuses on radionuclides, additional nonradiological parameters may have to be added to the analyte list to ensure that all contaminants of potential concern for the 100 Area are addressed. Specific analytes will need to be identified once groundwater characterization is completed in the 100 Area groundwater operable units. If contaminant inputs from non-Hanford-related operations are investigated under the modified program, it may be necessary to make the analyte list even broader. General water quality parameters, such as hardness and alkalinity, should be included in the monitoring program to assist in the evaluation of results. 
It is not anticipated that a broad list of parameters will need to be analyzed for during each round of sampling. After initial analysis for the broad spectrum of analytes, a shorter list for routine monitoring can be developed, and it is anticipated that the short 1 ist will be similar to the current list. During the evaluation-of-sampling-frequencies component of this activity, consideration should be given to how often analyses are required for the broad spectrum of analytes that is to be developed.

Finally, once the current surface-water monitoring program is modified and being implemented, this activity will serve to compile the information generated to allow for a definitive impact assessment.

Activity 2-2 - Surface Water Modeling.

Although the preliminary impact evaluation of this document does not show any adverse impacts to the overall river-water quality, there is the possibility for localized environmental effects. Investigation tasks have been proposed to collect data at specific sites regarding the interaction among groundwater, sediments, and river water. Some of these proposed data collection activities are focused on specific locations or contaminants (see Activity $1 A-3)$. To apply the data collected at one plume to another plume, a groundwater and surface-water dispersion model is needed to predict contaminant concentrations in the Hanford Reach that originate in other plumes. The model can be useful to minimize the necessity of extensive characterization activities at all plumes. The implementation of this activity will be dependent on the nature and extent of groundwater contamination identified during previous tasks. Model development would be justified only if there is significant risk-based groundwater contamination.

It is expected that contaminant flux data generated under Task 1 will serve as input to a surface water dispersion model, and the output of the model will allow for an assessment of impacts associated with exposure to the water column of the Hanford Reach.

Before the modeling can be implemented, available models should be evaluated. It is recommended that the Hanford Site Risk Assessment Modeling Committee be tasked to implement the evaluation phase of this activity and that they also be tasked to recommend an appropriate model (or models). Once this selection is made and input data are available, the surface water modeling necessary to support a cumulative impact assessment can proceed under this activity.

2.2.2.3 Task 3 - Characterization of River Sediment Pathways. Contaminants entering the Hanford Reach from discharging groundwater that has been affected by 100 Area operations are retained or deposited, to some extent, within the river sediments. The sediment medium of the Hanford Reach is highly valuable because of its use as a fish spawning bed and its production of benthic organisms that in turn provide food to valued fish resources. The sediments of the reach may also be an important ultimate sink for many of the contaminants released from the 100 Area. Therefore, a definitive characterization of this pathway is important.

The one activity proposed under this task is to define impacts to the sediments through monitoring. 
Activity $3-1$ - River Sediment Monitoring.

While sediment monitoring has been conducted for the Hanford Reach, it has not been conducted as comprehensively as is the ongoing Hanford Site surface water monitoring program. A lack of sediment quality criteria and difficulty in sampling sediments from an armored substrate in a swift current provide at least a partial explanation for the absence of a comprehensive sediment monitoring program. However, given the importance of this medium, as noted above, it is essential that a comprehensive program be developed and implemented.

A DOW for sediment sampling in the 100 Area segment of the Hanford Reach has been developed. The implementation of this DOW consisted of the first phase in the development of an appropriate and comprehensive river sediment monitoring program. The sediment DoW focused on sampling in likely areas of contaminant deposition, such as the production reactor outfall pipelines, islands, and within backwater slough areas between B Reactor and the Hanford Townsite. Control samples upstream of the 100-BC Area were also to be obtained to allow for determination of the presence of contamination. Sampling was completed in November 1992.

Contaminants of concern were based on contaminants known to be present in the effluent from the pipelines and the springs/seeps. Other noncontaminant parameters, such as TOC and mineralogy, were also considered for inclusion as they may be important in the overall characterization of the nature, extent, and effect of river sediment contamination. However, they were not analyzed for on the premise that significant levels of contaminants should be documented first. A determination of particle-size/concentration relationships was also made, which helps indirectly indicate potential levels of TOC.

Sediment sampling efforts were restricted to depositional zones, where contaminants are expected to accumulate. If adverse impacts are encountered, additional zones of sediment disposition within the channel will be identified and targeted for additional sampling.

If a long-term sediment monitoring program is developed and implemented, this activity will serve to compile the information generated to allow for a definitive impact assessment.

Another and highly significant data gap identified during the course of developing the preliminary impact assessment is the lack of sediment quality criteria, including even the lack of a generally accepted approach from which surrogate criteria can be developed. Without such an ability, one cannot determine whether contaminant levels encountered within the river sediments have the potential to result in a significant adverse impact to organisms. The EPA and Ecology are currently in the process of developing freshwater sediment quality criteria. Therefore, these agencies should be consulted during the implementation of this activity.

2.2.2.4 Task 4 -Characterization of Biological Pathways. A wide variety of human and nonhuman receptors have a potential of being exposed to contaminants entering the Hanford Reach from discharging groundwater that has been affected by 100 Area operations. Because the ecology of the 
Hanford Reach has been extensively studied for almost five decades, there are relatively few data needs required to allow for a cumulative impact assessment.

Three activities are proposed under this task and are discussed below, one to compile ecotoxicological data specific to 100 Area contaminants, the second to compile the results of ongoing biocontaminant monitoring efforts, and the third to compile information on the locations and species composition of sensitive and critical habitats within and along the Hanford Reach.

Activity 4-1 - Compilation of Ecotoxicological Data.

The purposes of this activity are to conduct a literature review to obtain valid ecotoxicological data for 100 Area contaminants and to obtain recommendations on approaches for developing sediment quality criteria.

In the course of developing the preliminary impact assessment presented in this report, no aquatic ecotoxicological data for ${ }^{99} \mathrm{Tc}$ were found. In addition, the ecotoxicological information for uranium indicates that this element has a very low aquatic toxicity; however, the values found in the literature may be a reflection of the insolubility and density of uranium. In other words, the aquatic bioassays performed may show a low toxicity due to the fact that uranium has a low solubility, which results in virtually no actual exposure to the experimental organisms.

Activity 4-2 - Compilation of Biocontaminant Monitoring Data.

Biocontaminant monitoring of various populations within the Hanford Reach is undertaken annually as part of the sitewide environmental monitoring program. This activity will include the compilation of the results of this annual program. In addition, this activity will include the compilation of the results of further biocontaminant monitoring efforts that are being conducted under the 100 Area groundwater operable unit work plans under development. These efforts are detailed in Appendix $D$ to groundwater operable unit work plans (e.g. DOE-RL 1992c); therefore, they are briefly summarized below.

The biocontaminant monitoring effort being undertaken in the 100 Area segment of the Hanford Reach has three main objectives:

- To determine the aquatic species of interest and the composition of the aquatic community

- To identify and evaluate potential aquatic biocontamination transport pathways

- To evaluate existing biocontaminant concentrations within representative populations.

This biocontaminant monitoring effort will provide the information needed to refine the conceptual understanding of environmental and human exposures to 100 Area contaminants. The information of species composition and species of interest can be used to identify appropriate ecological 
receptors for consideration in subsequent basel ine environmental evaluations. It can also be used to assess potential impacts to biota that may be part of the human food chain. The evaluation of the existing levels of contaminants and the biotic pathways for transport of contaminants provides information to identify appropriate environmental endpoints for use in assessing impacts to ecological receptors and may be useful in estimating human exposures.

\section{Activity 4-3 - Compilation of Sensitive and Critical Habitat Information.}

The National $0 i 1$ and Hazardous Substances Pollution Contingency Plan (40 CFR 300.430[e][2][i][G]) requires that a baseline risk assessment contain an environmental evaluation that assesses threats to the environment, especially critical and sensitive habitats. In order to conduct a cumulative impact assessment on the Hanford Reach, information on the location, nature, and species composition of such habitats within and along the Reach needs to be compiled. This compilation will be undertaken in accordance with the guidance provided in DOE-RL (1992a).

To assist in evaluating potential human exposures to aquatic biological organisms that may be contaminated from 100 Area operations, this activity will also include the compilation of the types, locations, and uses of species, particularly riparian species, that are known to be utilized by humans.

In November 1993, part of this activity was completed with the publication of $A$ Synthesis of Ecological Data from the 100 Areas of the Hanford Site, (Weiss and Mitche11 1992). This document summarized the current results of the environmental monitoring programs, 1 isted all known wildlife and plant species on the Hanford Site, compiled all previously identified food webs and contaminant pathways, and identified potential ecological receptors and assessment endpoints. Other documents in progress are the final reports on CERCLA-related 100 Area aquatic and terrestrial biota sampling for periphyton, caddisfly larvae, reed canary grass, asparagus, tree leaves, mammal and ant burrow soil from waste sites, coyote scat, and raptor pellets (the activities detailed in Appendix $D$ to groundwater work plans, as described above). These additional documents will complete activity $4-2$.

\section{Activity 4-4 Data Evaluation.}

Data compiled during other activities will be evaluated against the needs of the risk assessment to determine if further data gaps are identified. If data gaps are present, additional sampling programs may be recommended.

\subsubsection{Proposed Schedule}

Table 1-1 is a proposed schedule for initiation of the tasks included in this document. This table indicates either start of activity (assuming models are approved, if applicable, or dependent data are available) or date DOW is due to regulators for review. A meeting will be held with the EPA and Ecology to define the scope of all the work tasks (except sediment 
sampling; the DOW for that project was submitted in July 1992 to allow sufficient time for plannins field work).

On January 25, 1994, after this Columbia River Impact Evaluation Plan was sent for public review, the Tri-Party Agreement signatories established new milestones $(M-13-80,-80 A$, and $-80 B)$ known as the "Columbia River Comprehensive Impact Assessment." While work already begun under the old Milestone M-30-02 is being completed, other work (Tisk $1 A-3$, and Conditional Tasks 1B-1, 1B-2, 2-2, and 3-1b) have not yet begun. To begin these tasks with the limited 100 Area forus possible under Milestone M-30-02, when the mechanism exists to evaluate these tasks. for the entire Hanford Reach, would be counterproductive. Consequently, the listing for these tasks in the schedule has been changed to "Referred to Milestones M-13-80." This will ease their integration with public input, data needs for other areas, and results from other areas. They will not be initiated under M-30-02. 
Table 1-1. Proposed Activity Schedule.

\begin{tabular}{|c|c|c|c|}
\hline Activity & start & End & Deliverable \\
\hline $\begin{array}{l}\text { 1) } 1 \mathrm{~A}-1 \\
\text { ID Contaminants of Concern }\end{array}$ & December 1992 & $\begin{array}{l}\text { Concurrent } \\
\text { with RIs }\end{array}$ & $\begin{array}{l}\text { Operable Unit LFI } \\
\text { Reports }\end{array}$ \\
\hline $\begin{array}{l}\text { 2) } 1 A-2 \\
\text { Characterize Groundwater Flux to the River }\end{array}$ & October 1992 & $\begin{array}{l}\text { Conclusion of } \\
\text { Feasibility } \\
\text { studies }\end{array}$ & $\begin{array}{l}\text { Operable Unit } \\
\text { Feasibility } \\
\text { Studies }\end{array}$ \\
\hline $\begin{array}{l}\text { 3) } 1 A-3 \\
\text { Characterize Flux Mixing in River }\end{array}$ & $\begin{array}{l}\text { Referred to } \\
\text { Milestone } M-30-80\end{array}$ & & \\
\hline $\begin{array}{l}\text { 4) } 1 A-4 \\
\text { Chromium speciation }\end{array}$ & $\begin{array}{l}\text { October } 1992 \\
\text { Literature Review } \\
\text { April 1993* }\end{array}$ & September 1994 & $\begin{array}{l}\text { Supporting } \\
\text { Document }\end{array}$ \\
\hline $\begin{array}{l}\text { 5) } 1 \mathrm{~B}-1 \\
\text { ID Non-Hanford Sources (Conditional) }\end{array}$ & $\begin{array}{l}\text { Referred to } \\
\text { Milestone } M-30-80\end{array}$ & & \\
\hline $\begin{array}{l}\text { 6) } 18-2 \\
\text { Characterize Non-Hanford Sources } \\
\text { (Conditional) }\end{array}$ & $\begin{array}{l}\text { Referred to } \\
\text { Milestone } M-30-80\end{array}$ & & \\
\hline $\begin{array}{l}\text { 7) } 2-1 \\
\text { Surface Water Monitoring (To be conducted } \\
\text { through PNL's Site Monitoring Program) }\end{array}$ & July 1993 & July 1994 & $\begin{array}{l}\text { Supporting } \\
\text { Document }\end{array}$ \\
\hline $\begin{array}{l}\text { 8) } 2-2 \\
\text { Model Surface-Water Dispersion } \\
\text { (Conditional) }\end{array}$ & $\begin{array}{l}\text { Referred to } \\
\text { Milestone } \mathrm{M}-30-80\end{array}$ & & \\
\hline $\begin{array}{l}\text { 9) 3-1a } \\
\text { Sediment sampl ing }\end{array}$ & November 1992** & August 1993 & $\begin{array}{l}\text { Supporting } \\
\text { Document Completed } \\
\text { Heiss } 1993\end{array}$ \\
\hline $\begin{array}{l}\text { 10) } 3-1 \mathrm{~b} \\
\text { Identify Additional Depositional Areas } \\
\text { (Conditional) }\end{array}$ & $\begin{array}{l}\text { Referred to } \\
\text { Milestone } M-30-80\end{array}$ & & \\
\hline $\begin{array}{l}\text { 11) 4-1 } \\
\text { Compile Ecotoxicological Data }\end{array}$ & January 1993 & April 1994 & $\begin{array}{l}\text { Supporting } \\
\text { Document }\end{array}$ \\
\hline $\begin{array}{l}\text { 12) } 4-2 \\
\text { Compile Biocontaminant Data }\end{array}$ & Completed & November 1992 & WHC-EP-0601 \\
\hline $\begin{array}{l}\text { 13) } 4-3 \\
\text { Compi le Habitat Information }\end{array}$ & October 1992 & December 1993 & $\begin{array}{l}\text { Supporting } \\
\text { Document } \\
\text { Completed Downs et } \\
\text { al. } 1994\end{array}$ \\
\hline $\begin{array}{l}\text { 14) } 4-4 \\
\text { Evaluate Data with Risk Assessment Needs }\end{array}$ & $\begin{array}{l}\text { Concurrent with } \\
\text { ldentifying } \\
\text { Receptors in Risk } \\
\text { Assessment }\end{array}$ & & $\begin{array}{l}\text { Part of Risk } \\
\text { Assessment Process }\end{array}$ \\
\hline
\end{tabular}

*Regulator-approved (DOW) to be completed before field sampling

**DOW approved October 1993 


\subsection{REFERENCES}

Beanlands, G.E., and P.N. Duinker, 1983, An Ecological Framework for Environmental Impact Assessment in Canada, Institute for Resource and Environmental Studies, Dalhousie University, Halifax, Nova Scotia.

DOE-RL, 1991, Hanford Federal Facility Agreement and Consent Order Change Packages, 91-TPA-111, U.S. Department of Energy, Richland, Washington.

DOE-RL, 1992a, Hanford Site Baseline Risk Assessment Methodology, DOE/R1-91-45 Revision 2, U.S. Department of Energy, Richland, Washington.

DOE-RL, 1992b, Sampling and Analys is of 100 Area Springs, DOE/RL-92-12, U.S. Department of Energy, Richland Operations Office, Richland, Washington.

DOE-RL, 1992c, Remedial Investigation/Feasibility Study Work Plan for the 100-BC-5 Operable Unit, Hanford Site, Richland, Washington; Draft B, DOE/RL 90-08, U.S. Department of Energy, Richland Operations Office, Richland, Washington.

Downs, J.L., W.H. Rickard, C.A. Brandt, L.L. Cadwe11, C.E. Cushing, D.R. Geist, R.M. Mazaika, D.A. Neitzel, L.E. Rogers, M.R. Sackschewsky, and J.J. Nugent, 1994, Habitat Types on the Hanford Site: Wildlife and Plant Species of Concern, PNL-8942, Pacific Northwest Laboratory, Richland, Washington.

Dragun, J., 1988, The Soil Chemistry of Hazardous Materials, Hazardous Materials Control Research Center, Silver Springs, Maryland.

Ecology, EPA and DOE-RL, 1989, et seq., Hanford Federal Facility Agreement and Consent Order, Washington Department of Ecology, Olympia, Washington, U.S. Environmental Protection Agency, Region X, Seattle, Washington, and U.S. Department of Energy, Richland Operations Office, Richland, Washington.

EPA, 1987, Data Quality Objectives for Remedial Response Activities, EPA/540/G-87/003, U.S. Environmental Protection Agency, Office of Emergency and Remedial Response and Office of Waste Programs Enforcement, Washington, D.C.

National Research Council, Committee on the Applications of Ecological Theory to Environmental Problems, 1986, Ecological Knowledge and Environmental Problem-Solving, National Academic Press, Washington, D.C.

Syracuse Research Corporation, 1991, Toxicological Profile for Chromium, Agency for Toxic Substances and Disease Registry.

Weiss, S.G., 1993, 100 Area Columbia River Sediment Sampling, WHC-SD-EN-TI-198, Rev. 0, Westinghouse Hanford Company, Richland, Washington.

Weiss, S.G. and R.M. Mitchel1, 1992, A Synthesis of Ecological Data from the 100 Areas of the Hanford Site, WHC-EP-0601, Westinghouse Hanford Company, Richland, Washington. 


\section{DISTRIBUTION}

\section{Number of Copies}

\section{Onsite}

U.S. Department of Energy. Richland Operations Office

K.M. Thompson (40)

A5-19

B.L. Foley (10)

Public Reading Room (1)

A5-19

A $1-65$

7 Pacific Northwest Laboratory

R.L. Dirkes (5)

K6-61

P.W. Eslinger

$\mathrm{K} 6-52$

Hanford Technical Library

P8-55

43 Westinghouse Hanford Company

Central Files

L8-04

Correspondence Control

A3-01

EDM Group (2)

EPIC (7)

ERE Project File

ERC Records Center

ER Program Office (2)

H6-01

H6-08

$\mathrm{H} 6-04$

H6-07

$\mathrm{H} 2-27$

$\mathrm{H} 4-17$

Resource Center

N3-05

L.D. Arnold

B2-35

J.M. Ayres

R.L. Biggerstaff

$\mathrm{H} 6-02$

A.S. Carlson (10)

$\mathrm{H} 6-02$

B3-35

R.P. Hencke]

$\mathrm{H} 6-02$

A.D. Krug

V.G. Johnson

$\mathrm{H} 6-02$

H6-06

N.K. Lane

H6-01

N.M. Naiknimbalkar

H6-02

R.E. Peterson

J.W. Roberts

S.G. Weiss (5)

H6-06

$\mathrm{H} 6-02$

H6-02 

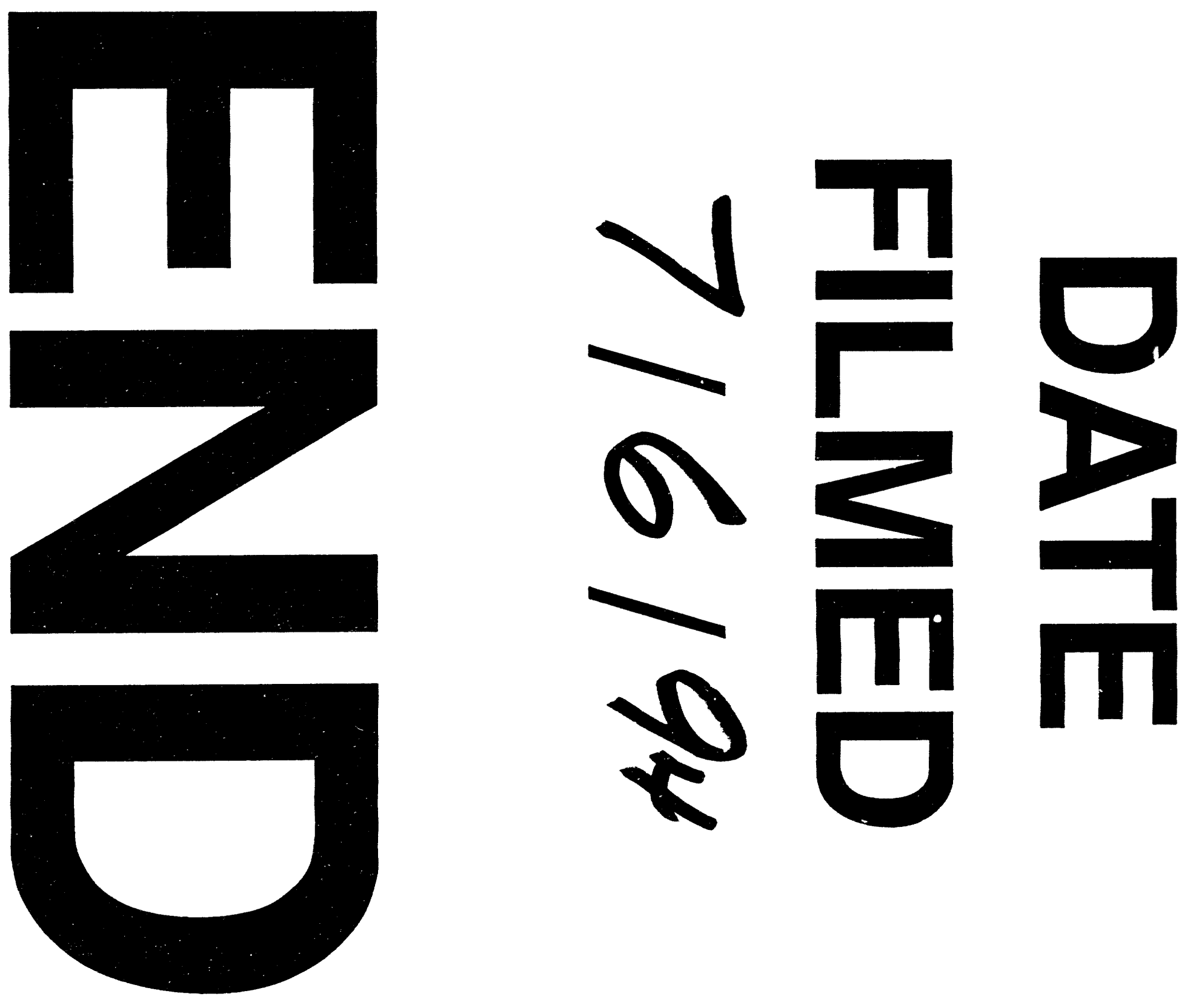

$x$ 
